\title{
Quantitative Comparison of the Proteolytic Enzyme Actinidin in Fresh Kiwifruit and the Commercial Kiwifruit Extract KWD+ ${ }^{\circledR}$
}

\author{
Almodóvar $\mathbf{P}^{1}$, González Hedström $\mathrm{D}^{1,2}$, Jarama ${ }^{1}$, Salamanca $\mathbf{A}^{1}$ and Inarejos García $\mathbf{A M}^{* 1}$ \\ ${ }^{1}$ Pharmactive Biotech Products SL, Madrid Science Park, Spain \\ ${ }^{2}$ Department of Physiology, Faculty of Medicine, Spain \\ *Corresponding author: Antonio Manuel Inarejos-García, Pharmactive Biotech Products, Madrid, Spain
}

\section{ARTICLE INFO \\ Received: 㗀January 28, 2019 \\ Published: 慧 February 07, 2019}

Citation: Almodóvar P, González Hedström D, Jarama I, Salamanca A, Inarejos García AM. Quantitative Comparison of the Proteolytic Enzyme Actinidin in Fresh Kiwifruit and the Commercial Kiwifruit Extract KWD+®. Biomed J Sci \& Tech Res 14(2)-2019. BJSTR. MS.ID.002519.
ABSTRACT

The aim of the present study was to analyse and to compare the proteolytic enzyme actinidin content of fresh kiwifruit (Actinidina deliciosa) and the commercial kiwi extract $\mathrm{KWD}+\AA$. The total protein extract was quantified by Bicinchoninic Acid Assay subjected to electrophoretic separation on an SDS-PAGE gel by "Coomassie brilliant blue" stain, the identification of Actinidin-A by immunoassay and the quantification with the corresponding purified standard. The actinidin concentration of KWD+® was about 5 fold higher than fresh kiwifruit (from 4.1 to $0.8 \mathrm{mg}$ of actinidin per grams of the sample). The standardization to actinidin in KWD+ $₫$ allows to stablish a concrete dosage to improve the digestion of some proteins difficult to digest such as gluten, soy protein or beef muscle.

Keywords: Actinidina Deliciosa; Kiwifruit Extract; Actinidin; Proteolytic Enzyme; Gluten; Digestion

\section{Introduction}

Kiwifruit (Actinidia deliciosa) is an exceptional source of nutrients such as vitamin $C$, and other bioactive components related to its healthy effects such as metabolic health, digestion, antioxidant activity and immune function [1].One of the best-known properties of kiwi consumption is the improvement of protein digestion due to the presence of actinidin (EC 3.4.22.14), a proteolytic enzyme [2]. There are several In vitro and In vivo studies that show the proteolytic effect of actinidin from kiwifruit in different food proteins such as gluten, soy protein or beef muscle [3-6]. The aim of this research work was to study the actinidin content of a new kiwifruit extract, and to compare it with the whole kiwifruit.

\section{Materials and Methods}

\section{Materials}

The commercial kiwifruit extracts $(K W D+\AA)$ provided by Pharmactive Biotech Products together with the fresh kiwifruit in powder form (which consists of a fresh kiwifruit freeze-dried), were stored in darkness at room temperature previous to analyses.

\section{Quantification of Actinidin and Total Protein Content}

The fresh kiwifruit powder(KP) and $\mathrm{KWD}+{ }^{\circledR}$ samples were previously prepared according to Martin (2016) to extract the protein components. Briefly, $500 \mathrm{mg}$ of sample was subjected to a non-reductive lysis of the lipids by incubation for $16 \mathrm{~h}$ at 4 ${ }^{\circ} \mathrm{C}$ in the presence of $2 \mathrm{~mL}$ of buffer. The resultant solution was centrifuged, and the soluble phase (supernatant that contains actinidin) was stored. The total protein extract was quantified by BCA (Bicinchoninic Acid Assay; Thermo Fisher Scientific, Massachusetts, USA), which was subjected to electrophoretic separation on an SDS-PAGE gel (12\%). The total protein profile was performed by "Coomassie brilliant blue" stain (BioRad, California, USA) and the identification of Actinidin-A by immunoassay using a polyclonal antibody anti-actinidin A (anti-Cp2, Agrisera antibodies, Vännäs, Sweden), and visualised with an anti-rabbit peroxidase as secondary antibody. The quantitative analysis of Actinidin was performed with the purified standard Actinidin (KiwiEnzyme Ltd, New Zealand), the concentrations employed were between 1 to 200 $\mu \mathrm{g} / \mu \mathrm{L}$. In addition, a pattern of BSA concentrations was performed, 
with a range between 0.5 at $40 \mu \mathrm{g} / \mu \mathrm{L}$. The quantification of Actinidin and total protein content was performed by digital images on protein gels and blots using the processing software Fiji (https://fiji.sc/).

\section{Results and Discussion}

\section{Actinidin and Total Protein Quantification}

Coomassie brilliant blue staining of the KWD+® and KP samples have a major band between $30-35 \mathrm{KDa}$, which was identified as Actinidin A using immunoblot techniques (antibodies reactive against Actinidin A), with more than $70 \%$ of its total protein content as can be seen in Figure $1 \mathrm{~A}$ Apart from actinidin A, other three bands of lower molecular weight were observed, which contribute 18-28 \% to the total protein content of each sample (data not shown). Nevertheless, KWD+® sample showed about 5-fold higher levels of Actinidin A compared to the fresh kiwifruit (KP) samples (Figure 1B) $\mathrm{P} \leq 0.01$. Kiwifruit has a low protein content, being the actinidin more than $50 \%$ of the total protein content, which agrees with the results obtained by other authors [7-11]; in the case of the new $\mathrm{KWD}+\circledR$, the actinidin content (in percentage) represent more than $80 \%(82 \pm 9 \%)$ of the total protein, and KP was slightly lower $(74 \pm 5 \%$ Figure $1 \mathrm{~A})$. However, the actinidin content in $\mathrm{KWD}+\AA$ (4.1 $\pm 0.9 \mathrm{mg}$ actinidin/g sample) was significantly higher compared to KP (0.8 $\pm 0.3 \mathrm{mg}$ Actinidin/ g of sample; (Figure 1B)).
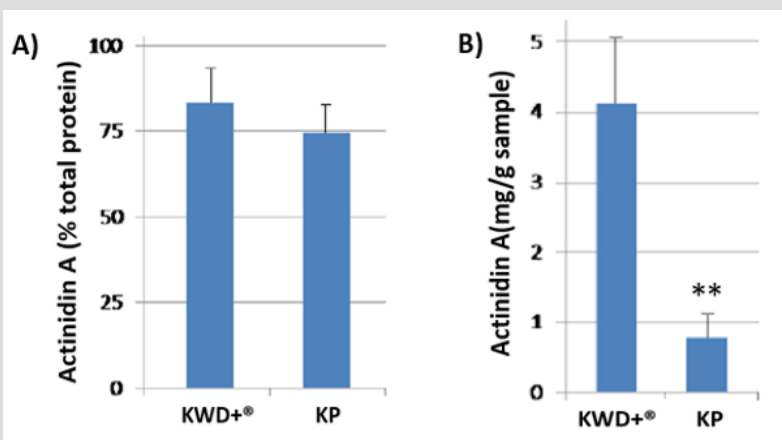

Figure 1:

Actinidin A concentration based on A) total protein content (\%) and B) Actinidin A content (mg/g sample) in KWD® and KP samples

\section{Conclusion}

The extraction processing technology may increase the actinidin concentration at least 5-fold in the KWD+® extract compared to the fresh kiwifruit, and therefore, the development of a new kiwifruit extract standardized to actinidin may improve the digestion of specific proteins difficult to digest using an adequate dosage.

\section{References}

1. Kaur L, Rutherfurd SM, Moughan PJ, Drummond L, Boland MJ (2010) Actinidin enhances protein digestion in the small intestine as assessed using an in vitro digestion model. J Agric Food Chem 58(8): 5074-5080.

2. Kaur L, Rutherfurd SM, Moughan, PJ, Drummond L, Boland MJ (2010) Actinidin enhances gastric protein digestion as assessed using an in vitro gastric digestion model. J Agric Food Chem 58(8): 5068-5073.

3. Lewis DA, Luh BS (1988) Development and Distribution of Actinidin in Kiwifruit (Actinidia Chinensis) and Its Partial Characterization. J Food Biochem 12: 109-116.

4. Montoya CA, Hindmarsh JP, Gonzalez L, Boland MJ, Moughan PJ, et al. (2014) Dietary Actinidin from Kiwifruit (Actinidia deliciosa cv. Hayward) Increases Gastric Digestion and the Gastric Emptying Rate of Several Dietary Proteins in Growing Rats. J Nutr 144(4): 440-446.

5. Nishiyama I (2007) Fruits of the Actinidia genus. Adv Food Nutr Res 52: 293-324.

6. Praekelt UM, McKee RA, Smith H (1988) Molecular analysis of actinidin, the cysteine proteinase of Actinidia chinensis. Plant Mol Biol 10(3): 193202.

7. Préstamo G (1995) Actinidin in kiwifruit cultivars. Z Lebensm Unters Forsch 200(1): 64-66.

8. Harry Martin (2016) Quantification of Functional Actinidin in Whole Kiwifruit Extract Using the Selective Cysteine Proteinase Inhibitor 4(4): 243-250.

9. Rutherfurd SM, Montoya CA, Zou ML, Moughan PJ, Drummond LN, et al. (2011) Effect of actinidin from kiwifruit (Actinidia deliciosa cv. Hayward) on the digestion of food proteins determined in the growing rat. Food Chem 129(4): 1681-1689.

10. Singletary K (2012) Kiwifruit: Overview of Potential Health Benefits. Nutr Today 47(3): 133-147.

11. Stonehouse W, Gammon CS, Beck KL, Conlon CA, Von Hurst PR, et al. (2013) Kiwifruit: our daily prescription for health. Can J Physiol Pharmacol 91(6): 442-447.
ISSN: 2574-1241

DOI: 10.26717.BJSTR.2019.14.002519

Antonio Manuel Inarejos-García. Biomed J Sci \& Tech Res

This work is licensed under Creative Commons Attribution 4.0 License

Submission Link: https://biomedres.us/submit-manuscript.php

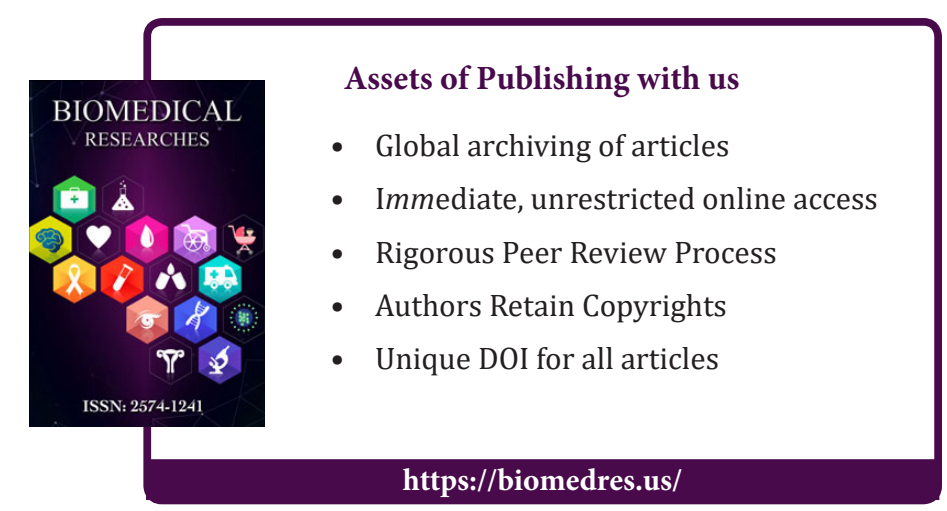

